\title{
Who are Steered to a Risky Credit Alternative?
}

The market for a payday advance, regarded as both a convenient and short term-loan for immediate financial help, has grown incredibly since the 1990's. Despite its popularity by borrowers and the possible benefits, it has received negative publicity. Some borrowers have been caught in a debt trap for a long-term period and at tripledigit interest rates. The objective of this study is to shed light on the borrowers' profiles and their demand for a payday advance. Based on the 2010 household level data from the U.S. Federal Reserve Board, this study finds that payday advance users are pronounced as seemingly risky people. Payday advance users tend to be college drop-outs, African Americans, and non-homeowners compared to non-payday advance users. They are more likely to overspend above their income and have a favorable attitude toward conspicuous spending than non-payday advance users. They tend not to shop at all nor perform even moderate shopping for credit before using a payday advance service as opposed to nonpayday advance users.

Recent consumers use different types of personal loans such as credit cards, mortgage loans, installment loans and payday advances for diverse purposes. Among these types of personal loans, a payday advance, known as a payday loan, is a small, shortterm unsecured loan provided by payday lenders, regardless of whether repayment of loans is linked to a debtor's payday. It is often advertised as a convenient, short term, and lower-cost credit product as opposed to bouncing a check, paying service

Instructor, Department of Home Economics Education, College of Education, Korea University (Jay.jongheelee@gmail.com)

Key Words: Payday Advance; Payday Advance Users; The Survey of Consumer Finances charges for a returned check, or accruing fees for late payments (Logan and Weller, 2009).

Despite its popularity from borrowers and the possible benefits, a payday advance has received negative publicity for several reasons. First, in general a payday advance is expensive. The high annual percentage rate is one reason it is controversial. The APR on a two-week loan is almost 390 percent (Morgan and Pan, 2012). Secondly, the steering of borrowers into high-cost loans has been pronounced toward the seemingly risky borrowers such as lowincome earners and racial/ethnic minorities (Morgan and Pan, 2012) or to senior citizens (Macy, 2010). These facts have contributed to inequalities in wealth-building among these groups. Third, although a payday advance has been advertised as a two-week product, many borrowers tend to roll over this loan multiple times (Baddour, 2009). Due to this high rollover rate, borrowers might be trapped into a destructive cycle of debt (Morgan and Pan, 2012). In fact, average borrowers end up being indebted for nearly half of the year (The PEW Charitable Trusts, 2013). In addition, the features of payday advances such as a lack of underwriting, single balloon payments, and having access to a borrower's checking account as collateral result in many borrowers having no choice but to obtain more loans to repay the original one (Consumer Federation of America, 2012). Lastly, the choice to use a payday advance is often determined by unrealistic expectations and through desperation. Payday advance users tend to perceive the loans to be a reasonable short-term choice when they obtain them but express frustration at the long period of time required to repay the loans (The PEW Charitable Trusts, 2013). 
Regardless of the skyrocketing household debt in South Korea, some households still have some difficulties borrowing money from a mainstream financial institution and they tend to borrow money from non-bank loans and other financial services (Financial News, 2013). An increasing trend in credit default in South Korea has been pronounced among those who borrow money from payday lender types of credit providers (Seoul News, 2012). A payday advance has been a large segment of the subprime lending industry (Macy, 2010). Despite the gradual growth over the last fifteen years in the U.S., payday lending remains a niche financial product targeting subprime borrowers (Bianchi, 2012). Especially almost $26 \%$ of Americans, reaching 39 million people, are either "unbanked (i.e. not having their own bank accounts)" or "underbanked (i.e. having poor access to mainstream financial services)" (Bianchi, 2012). These people without access to mainstream financial services may be caught in the payday lenders' debt trap.

The objective of this study is to shed light on the borrowers' profiles and their need and demand for a payday advance by questioning them about the following: (1) If consumers are denied credit by mainstream lenders due to bad credit scores or filing for bankruptcy, would they borrow from a shortterm but high-cost credit business such as a payday advance? (2) If consumers find themselves in a financially hopeless situation, would they be steered into a payday advance for financial help? (3) If consumers have more knowledge about their available credit options by shopping around for credit products, would they be less likely to use the short-term but high-cost credit alternative, like a payday advance?

\section{THEORETICAL BACKGROUND}

\section{Rational Behind Payday Lending}

A payday advance can provide a desirable credit product that helps borrowers solve temporary cashflow problems caused by events such as an emergency (Financial Service Centers of America, 2009). Typically, the loan is repaid along with a fee from the borrower's next paycheck. Generally, this occurs within a two week timeframe (Casehet USA, 2012). Usually, the amount borrowed is small, ranging from $\$ 50$ to $\$ 1,000$ (Morgan and Pan, 2012). In order to use a payday advance, borrowers only need to prove that they are steady income earners. In particular, the loan applicants provide payday advance lenders with a bank statement and proof of employment and the lender may check the applicant's creditworthiness (Morgan and Pan, 2012). If the applicants are approved, the lender deposits the funds into their bank account on the following business day (Casehet USA, 2012). When the loan is due, the amount borrowed and other related fees are debited from the borrower's account (Morgan and Pan, 2012). If the borrowers do not have enough money remaining in their account to repay the loan on the due date, they need to choose from several pricey options (Logan and Weller, 2009).

Payday loans have been marketed as a convenient and a lower-cost alternative method to cover emergency expenses (Logan and Weller, 2009), even though there are other short-term credit alternatives available for urgent situations, such as using installment loans and pawn shop loans (Casehet USA, 2012). The payday advance can be less costly to some borrowers than other options of incurring late fees, having a check returned due to insufficient available funds, or using overdraft protection. It can make borrowers avoid the monetary consequences of using overdraft protection, and the non-monetary consequences of delinquent payments such as damage to a credit score (Bair, 2005).

\section{LITERATURE REVIEWS}

\section{Predatory Lending Practices}

Previous studies showed that payday advance lenders have been targeting the financially risky groups and the results suggested mixed findings. Prager (2009) reviewed the locations of payday lenders to examine if they target minority neighborhoods. It was found that payday lenders were more likely to be located in neighborhoods with disproportionately large Hispanic or African 
American populations. Margan and Pan (2012) examined households' payday credit usage by using the Survey of Consumer Finances. They found that the race gaps fall significantly after controlling for demographic and financial variables. Bhutta (2012) assessed whether payday lenders target minority neighborhoods using census data to determine where to place payday lender store locations. This study found that the racial composition did not influence the store locations after controlling for income, wealth and demographics in a statistical sense.

\section{Profiles of Payday Advance Users}

Previous studies demonstrated the borrowers' reasons for using a payday advance. Baddour (2009) found that the majority of the payday borrowers used the loans to pay for recurring basic expenses such as food, utilities, and housing. About $40 \%$ reported they could not obtain loans for the needed amounts from mainstream lenders. Using the Survey of Consumer Finances, Caplan (2011) examined the motivations for using a payday advance and the ability to use informal financial supports. This study found that men were more likely to use payday loans for emergencies and for convenience, while women were more likely to use the loans to pay other bills or to help family and friends. Macy (2010) found that many college students did not understand the true cost of payday loans. Also, it was found that only 7\% of Hispanic consumers who carry a balance reported any "substantial" shopping for credit, compared to $12 \%$ for a similar white counterpart. Ibarra and Rodriguez (2007) argued that a low amount of shopping for credit among individuals with credit card balances put consumers in a more financially vulnerable position.

\section{Consequences of Using A Payday Advance}

The consequences of using payday loans have been discussed at a high level in the U.S. Baddour (2009) found that over $50 \%$ of the payday advance borrowers rolled over their loans at least one time and As a result, the cost to borrow money often exceeded the original loan principal. Dunn and Mirzaie (2012) examined the level of stress attributed from the different types of debt by using the
Consumer Finance Monthly. It was found that debt was an obvious problem for many American households, not only economically but also psychologically. Consumer advocates argued that the credit industry has been targeting financially vulnerable people and that this practice leads these frequent payday advance users to be caught in a cycle of high-cost borrowing (Smale, 2005).

\section{Demand for Credit}

The foundation of understanding of the nature of borrowing begins with the Life Cycle-Permanent Income model (Betti, Dourmashkin, Rossi, \& Yin, 2007). This theory provides insight on rationale behind debt acquisition of consumers with budget constraints. In theory, household income and wealth invariably change over the life stages of consumers and consumers maximize their utility by smoothing their marginal utility over their lifetimes. Additionally, Crook (1996) showed that more years of schooling by a household head increase the household's demand for credit. Crook (2006) found that high assets and high borrowing were correlated since household assets would provide collateral for more borrowing. Several empirical studies also proved that consumers' psychological characteristics play an important role in the decision to borrow. For example, Lawrance (1991) examined the intertemporal preferences of U.S. households with the Panel Study of Income Dynamics. It was concluded that poor households tend to have relatively high rates of time preference and marginal propensities to spend and the rich and poor households encounter different borrowing propensities. Godwin (1998) examined changes in household levels of consumer debt with the Survey of Consumer Finances. A decrease in debt quintile was found to be commensurate with psychological variables such as future expectations and time preference.

\section{Problem Statement}

Previous studies have shown that payday lenders tend to provide services to those least able to afford their interest rates and that using a payday advance might result in not only financial but also emotional negative consequences to these people. However, the 
amount of literature is limited in that it has not controlled for the household-level characteristics that might influence the choice to use payday loans. It might be because survey data from the government has not been publicly available for a definitive analysis of the payday loan borrowers (Logan and Weller, 2009). In addition, although there is mounting evidence that financial literacy is an important determinant of saving, retirement planning, and investment in stocks, relationships in both financial literacy (more like debt literacy) and debt behavior have not been studied at the national level (Lusardi and Mitchell, 2007). In order to overcome the limitations from previous studies, this study aims to shed light on the borrowers' profiles and their demand for payday advances with the household-level survey.

\section{METHODS}

Data

This study uses the Survey of Consumer Finances (SCF). The SCF data has been conducted on a triennial basis by the Federal Reserve Board (Board of Governors of the Federal Reserve System, 2013). This data employs a sample design of a geographically based random sample and an oversample of the wealthy households (Bucks et al., 2009). In order to adjust for the survey nature of the dataset, the data are weighted accordingly. The data provides the information of those who acknowledged using a payday loan in the prior year (Logan and Weller, 2009). Also, the data specifically includes detailed information on household-level characteristics. This current study uses the 2010 SCF which is the latest version.

\section{Variable Identifications / Measurement}

Using A Payday Advance In order to measure whether a respondent uses payday advances, this study uses a question from the SCF asking "During the past year, have you (or anyone in your family living here) taken out a payday loan, that is, borrowed money that was supposed to be repaid in full out of your next paycheck?" The possible answers are "yes" or "no." If a respondent answers "yes", he/she is considered to have used a payday advance service.

Reasons For Using A Payday Advance The reasons for using a payday advance are measured by a question asking "Why did you choose this type of loan?" The answers are classified into five groups. First, if borrowers used a payday advance to buy gas, medicine/medical payments, pay utilities or rent, pay vehicle expenses other than for gas, they would be categorized as "basic expenses." Secondly, if borrowers used a payday advance to pay other bills/loans, they would be categorized as "Pay other bills/loans." Third, if borrowers used a payday advance to help family and prepare for emergency/needed quick money, their answer was placed into "emergency." Fourth, if borrowers used a payday advance for convenient purposes, then "convenience" was the category used. Fifth, if borrowers used a payday advance because they assumed that this was the only option available to them, then it was placed into "no option."

Debt-Related Characteristics Generally, if someone filed for bankruptcy, this designation remains on credit reports and the bankruptcy flag can legally stay on a bankruptcy filer's credit history for up to ten years after the filing has occurred. This fact might influence debtors' access to credit and interest rates. This study assumes that this bankruptcy flag can influence these borrowers' access to mainstream financial institutes and, therefore, it would make them utilize risky credit alternatives instead. Therefore, respondent's bankruptcy filing and being rejected for any request for credit by potential lenders are considered in the research model. Rejected credit applicants are measured by the question asking, "In the past five years, has a particular lender or creditor turned down any request you or your (husband/wife/partner) made for credit, or has not approved you for as much credit as you applied for?"

Attitudinal Characteristics The relationship between borrowers' spending patterns and their use of a payday advance is considered. In order to measure 
borrowers' spending patterns, several SCF questions are used. The indicator for overspending equals " 1 " if a respondent reports that he/she usually spends more than his/her income. The indicator equals " 0 " if a respondent reports that his/her spending is usually about the same as his/her household income or if it is less than his/her income. In addition, people can have many different reasons for borrowing money which they repay over a period of time. Questions asking whether a respondent thinks it is okay to use credit to pay or for living expenses if income decreases are incorporated into the research model. If a respondent answers "yes" to at least one of these questions, he/she is considered to have a positive attitude toward conspicuous spending.

When making major decisions about borrowing money or obtaining credit, some people shop around for the very best terms while others don't engage in this comparison activity. Those who do a great deal of shopping for credit would have more knowledge about it such as which options have better rewards or terms. On a scale from 1-5, where "1" represents "almost no shopping", and " 5 " indicates "intensive shopping", a respondent is asked whether he/she would be on the scale.

Demographics and Economic Characteristics Age groups are divided into segments of 35 and under, 35 - 44, 45 - 64, and 65 plus. The levels of educational attainment are divided into four categories which are less than high school, high school/GED, college dropout, college graduate and more than college graduate. The racial and ethnic identification is divided into four general categories which are White, African American, Hispanic, and Others. Income and net worth are divided into quartiles based upon the total household income and the sum of all household assets less any liabilities respectively. The respondent's marital status, gender, inclusion of children in the household, job status and homeownership are also provided in the research model.

\section{Empirical Model}

Table 1 and Figures 1-6 show findings from descriptive analyses based on the profile of payday advance users and the reasons for using a payday advance. Table 2 shows findings from multivariate analyses of the predicted probability of using a payday advance. The predicted probability is a function of three types of independent groups: (1) borrower's debt-related characteristics, (2) attitudinal characteristics, and (3) demographic and financial characteristics. The Chi-Square Test is performed to test for a relationship between categorical variables. Logistic regression is performed to estimate the predicated probability of using a payday advance.

\section{RESULTS}

\section{Descriptive Analyses}

The Table 1 and Figure 1-6 show that comparisons between those who used a payday advance and those who did not. It indicates that payday advance users and non-users unconditionally differ in a number of ways. Overall, about $4 \%$ of households surveyed reported having withdrawn a payday advance within one year prior to the 2010 SCF survey. This finding may appear to be a small portion of overall households, but the selected characteristics of the payday advance users and non-payday advance users are notably different. Given the possible negative consequences of using a payday advance loan, it is important to examine the potential variables that influence the probability of using this type of loan and the need for using it. Due to rounding, amounts reported in Table 1 , it may not exactly add to $100 \%$.

More than three times as large as a share of payday loan borrowers had previously been rejected for various types of a loan within the five years prior to the year of the survey. They were more rejected in applying for credit $(54.3 \%)$ as compared to nonpayday loan users (17.2\%). Payday advance users filed for bankruptcy two times in the past (28.6\%) than the non-payday advance users (12.4\%).

In terms of attitudes toward conspicuous spending, non-payday advance users have a negative or neutral attitude toward this type of spending than the payday advance users. This statistic is almost twice as high as that of payday advance users. Roughly $33 \%$ of payday advance users report that 
Table 1. Profile of Payday Advance Borrowers

\begin{tabular}{|c|c|c|c|c|}
\hline \multicolumn{2}{|c|}{ Independent Variables } & $\begin{array}{l}\text { Payday Advance } \\
\text { Borrower }\end{array}$ & $\begin{array}{l}\text { Non-Payday Advance } \\
\text { Borrower }\end{array}$ & $\chi^{2}$ \\
\hline \multicolumn{5}{|l|}{ Debt-Related Characteristics } \\
\hline \multirow[t]{2}{*}{ Rejected } & Yes & 54.29 & 17.02 & $<.0001$ \\
\hline & No & 45.71 & 82.98 & \\
\hline \multirow[t]{2}{*}{ Bankruptcy } & Yes & 28.64 & 12.38 & $<.0001$ \\
\hline & No & 71.36 & 87.62 & \\
\hline \multirow[t]{3}{*}{ Shop for Credit } & No Shopping & 35.54 & 27.50 & .0029 \\
\hline & Moderate Shopping & 33.73 & 31.81 & \\
\hline & Intensive Shopping & 30.72 & 40.69 & \\
\hline \multicolumn{5}{|l|}{ Attitudinal Characteristics } \\
\hline \multirow[t]{2}{*}{ Conspicuous Spending } & Yes & 93.02 & 86.67 & .0036 \\
\hline & No & 6.98 & 13.33 & \\
\hline \multirow[t]{2}{*}{ Spending Habit } & Overspending & 32.56 & 18.66 & $<.0001$ \\
\hline & Same /Less Spending & 67.44 & 81.34 & \\
\hline \multicolumn{5}{|l|}{ Demographics } \\
\hline \multirow[t]{4}{*}{ Age } & 35 and under & 31.06 & 20.56 & $<.0001$ \\
\hline & 35 to 44 & 24.00 & 17.92 & \\
\hline & 45 to 64 & 37.78 & 38.70 & \\
\hline & 65 plus & 7.16 & 22.82 & \\
\hline \multirow[t]{4}{*}{ Education } & Less than High School & 15.69 & 11.78 & $<.0001$ \\
\hline & High School/GED & 36.02 & 32.04 & \\
\hline & College Dropout & 27.96 & 18.20 & \\
\hline & College & 20.33 & 37.98 & \\
\hline \multirow[t]{4}{*}{ Race-Ethnicity } & White & 51.64 & 69.63 & $<.0001$ \\
\hline & African American & 29.53 & 12.92 & \\
\hline & Hispanic & 14.40 & 13.04 & \\
\hline & Others & 4.43 & 4.41 & \\
\hline \multirow[t]{2}{*}{ Marital Status } & Married & 32.63 & 50.58 & $<.0001$ \\
\hline & Not Married & 67.37 & 49.42 & \\
\hline \multirow[t]{2}{*}{ Child/Children } & Yes & 61.86 & 42.81 & $<.0001$ \\
\hline & No & 38.14 & 57.19 & \\
\hline \multicolumn{5}{|l|}{ Financial Characteristics } \\
\hline \multirow[t]{3}{*}{ Job Status } & Salary Earner & 65.25 & 56.66 & .0020 \\
\hline & Self Employed & 5.10 & 11.66 & \\
\hline & Retired/Not Working & 29.65 & 31.69 & \\
\hline \multirow[t]{4}{*}{ Income } & Low Income & 34.76 & 25.49 & $<.0001$ \\
\hline & Lower Middle Income & 37.42 & 23.88 & \\
\hline & Upper Middle Income & 19.79 & 24.17 & \\
\hline & High Income & 8.03 & 26.45 & \\
\hline \multirow[t]{4}{*}{ Net Worth } & Low Net worth & 52.45 & 23.93 & $<.0001$ \\
\hline & Lower Middle Net Worth & 37.26 & 24.51 & \\
\hline & Upper Middle Net Worth & 9.84 & 25.59 & \\
\hline & High Net worth & 0.46 & 25.98 & \\
\hline \multirow[t]{4}{*}{ Expected Future Income } & Same & 30.60 & 31.68 & .0010 \\
\hline & Increase & 10.98 & 9.64 & \\
\hline & Decrease & 14.23 & 23.98 & \\
\hline & Not Certain & 44.19 & 34.71 & \\
\hline \multirow[t]{2}{*}{ Homeownership } & Yes & 37.30 & 68.55 & $<.0001$ \\
\hline & No & 62.70 & 31.45 & \\
\hline
\end{tabular}

Income groups are divided at point of $\$ 24,396, \$ 45,742$, and $\$ 81,320$.

${ }^{2}$ Networth groups are divided at point of $\$ 8,400, \$ 77,100$, and $\$ 300,300$. 
they spend more than their income. This statistic is about twice as large as those who did not withdraw and use a payday advance. When making major decisions about borrowing money or obtaining credit, the payday advance users who do almost no shopping for borrowing options is $35.5 \%$. The rate is higher than that of non-users $(27.5 \%)$.

Those who acquire a payday advance tend to be younger than those who do not obtain an advance. About $31 \%$ of payday advance users are people younger than 35 and this percentage is 1.5 times higher than the percentage of non-payday advance users.

The largest share of payday advance users, about $36 \%$, have a high school degree or a GED, while the largest part of non-payday advance users, about 38\%, have a college degree. There are disproportionate racial and ethnic disparities between payday advance users and non-users. Even though whites represent a larger share of both the payday advance users and non-users, whites account for about $70 \%$ of the nonusers, but only about $51 \%$ of the users. The fact that more African Americans use the payday advance than any other groups is pronounced.

The mean and median incomes of those who utilize a payday advance are notably lower than those who do not use these loans. Those who take out a payday loan have lower net worth than those who go without using a payday advance. Approximately $38 \%$ of those who borrow from a payday lender own their home, while nearly $69 \%$ of nonpayday advance users are homeowners.

The majority of payday advance users report that they took out the loan for temporary emergencies (33.9\%). The second largest group of payday advance users responds that they use a payday advance because it is convenient (24.4\%). Other reasons for having the loan are paying for other bills/loans (17.5\%), basic expenses (12.6\%), and no other option (11.6\%). Figure 1-6 show the reasons for using a payday advance across selected groups. These groups were chosen because they are significantly more likely to take on a payday advance compared to other groups in the descriptive analyses. Figure 1 compares the reasons for using a payday advance between those who were credit constrained and

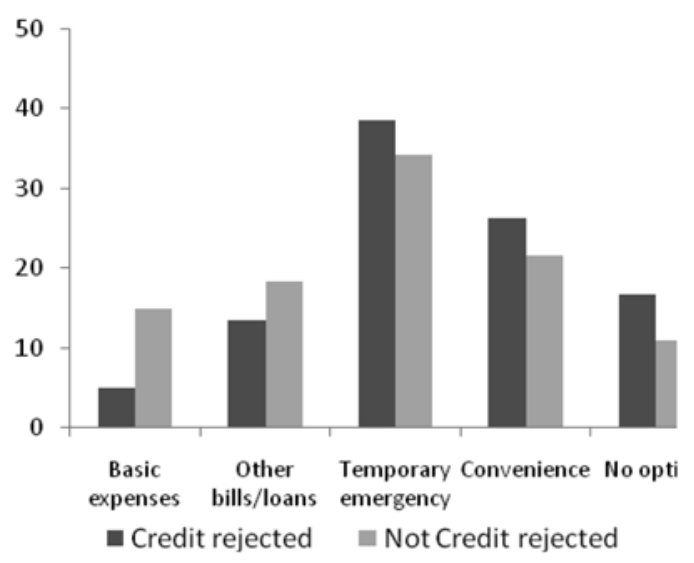

Figure 1. Borrowers' Demand by Credit Rejection.

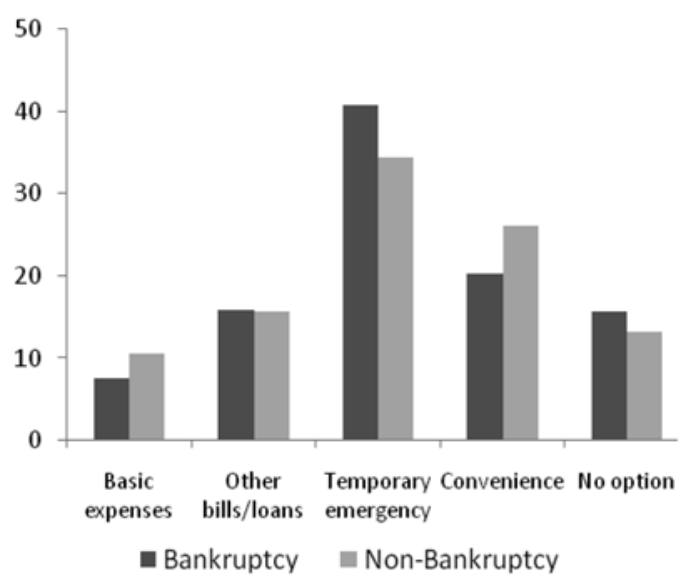

Figure 2. Borrowers' Demand by Bankruptcy.

those who were not. It shows that those who were credit constrained tend to use the payday advance for temporary emergency expenses. Also, they use the loan for convenience reasons and are more likely to think that there are no other available credit options. This trend is quite similar with the findings from Figure 2. Figure 2 shows the reasons for using a payday advance between bankruptcy filers and nonbankruptcy filers. Among those who previously filed for bankruptcy, the higher group answer "no other option". Figure 3 shows the reasons for having a payday advance for those who have a favorable attitude toward conspicuous spending. Those who had a favorable attitude toward conspicuous spending tend to use the payday loan for recurring expenses such as basic expenditures and other bills/loans. They tend to feel that there is no other credit 


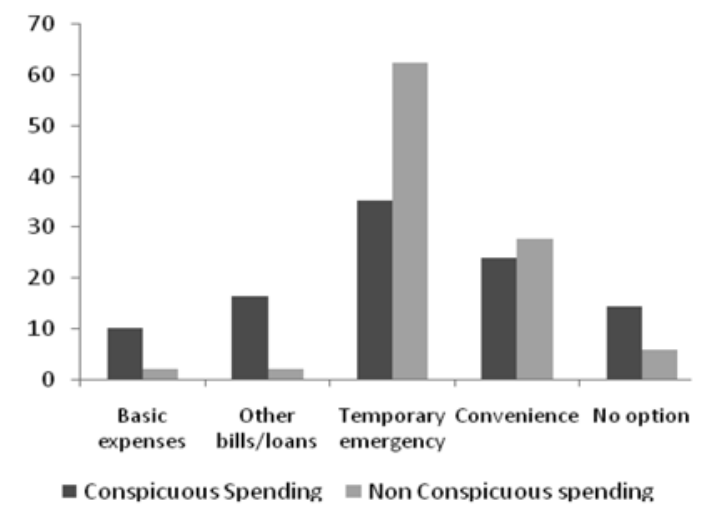

Figure 3. Borrowers' Demand by Spending Attitude.

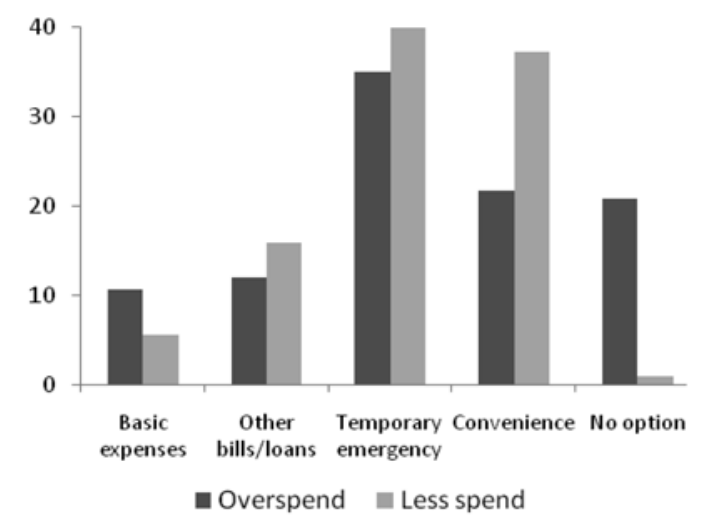

Figure 4. Borrowers' Demand by Spending Pattern.

alternative available to them. These findings are partly similar with the findings from Figure 4 . Those who spend more than their income cite the recurring expenses and no other option as the reasons for using a payday advance. As Figure 5 demonstrates, the much higher percentage among those who are college dropouts use the payday advance for basic expenses than other groups. They believe that there is no other credit alternative. As Figure 6 illustrates, African Americans tend to use the payday advance not only for temporary emergency situations but also for the convenience.

\section{Multivariate Analyses}

The unconditional comparisons in Table 1 suggest that those who are younger than age 35, those who have a high school degree, are white, single, salary earners, and people with the lower income and net worth are more likely to use a payday advance than

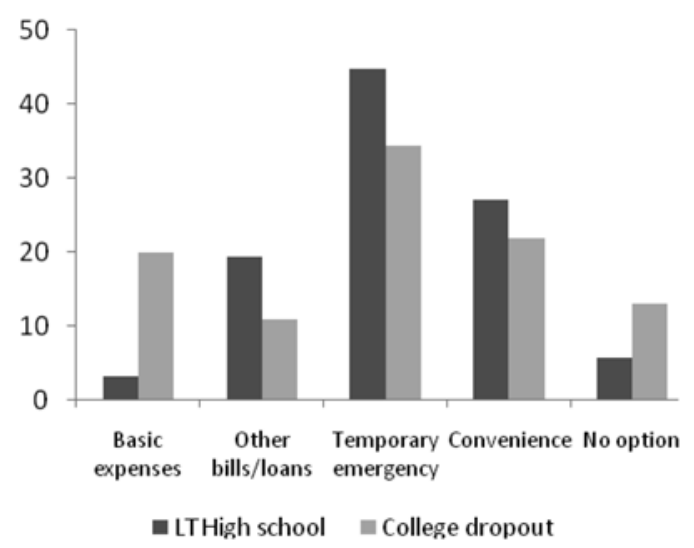

Figure 5. Borrowers' Demand by Education.

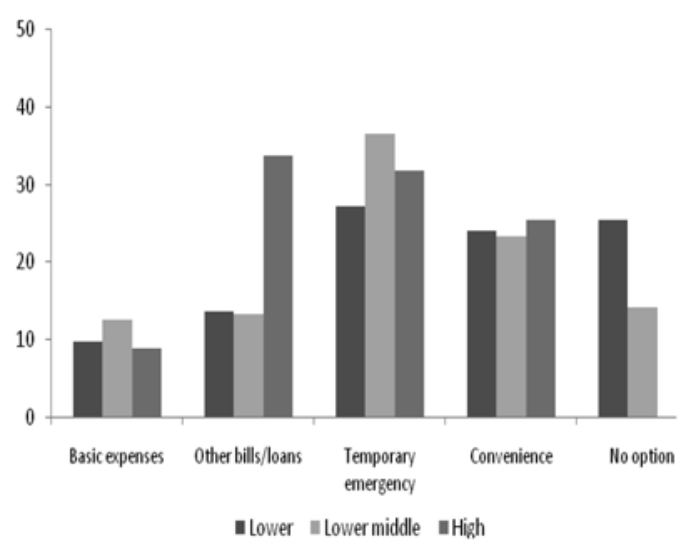

Figure 6. Borrowers' Demand by Income Level.

other groups. However, those comparisons do not control for other differences. Therefore, statistical models that determine the predicted probability that a borrower uses payday advance as a function of various control variables are used in the multivariate analyses. In particular, the research model examines the impact of credit constraint, the lack of information on borrowing options, the attitude toward spending and actual spending behavior. Whether the portion of variation in using a payday advance remains after controlling for demographics and financial traits is considered in the model.

Debt-Related Characteristics The effects for debtrelated characteristics are statistically significant even after controlling for other characteristics. It is found that those who experienced credit constraints are 2.4 times more likely to use payday advance loans than 
those who did not encounter credit concerns. Those who filed for bankruptcy in the past are about $74 \%$ more likely to borrow from a payday advance business over those who did not experience bankruptcy. Thus, this finding reflects that having other credit options plays an important role in borrowing from payday advance loans.

Attitudinal Characteristics The effects for attitudinal characteristics remain even after accounting for demographics and financial factors in the process. Those who generally spend more than their income are almost 2.6 times more likely to have a payday advance than those who spend equal to or less than their income. This finding indicates that the borrower's overspending behavior can lead to the person using funds provided through a payday advance. The effect of having a favorable attitude toward conspicuous spending on the predicted probability of using a payday advance has a positive sign. People having a favorable attitude toward this type of spending are about 1.5 times more likely to use payday advance loans than those who do not have this attitude. Doing significant exploratory shopping for credit creates negative associations with borrowing from a payday advance. These findings suggest that the more a borrower seeks information by shopping for credit, the less he/she uses a payday advance.

Demographic and Financial Characteristics The age of the respondent is related with the predicted probability of using a payday advance. Even though those aged younger than 35,35 to 64 , and 45 to 64 are not statistically different in terms of the probability, those who are older than 65 are notably less likely to use a payday advance than any other group. Respondent's educational attainment is associated with the likelihood of having a payday advance. However, it does not simply mean that payday advance users are not the least educated people. It is because there is a statistically positive effect of being a college dropout on the probability of using a payday advance. They are more likely to have the advanced loan than those who have less than a high school degree and those who have the high
Table 2. Multivariate Analyses of Selected Independent Variables

\begin{tabular}{|c|c|c|c|}
\hline Parameters & Estimates & S.E. & Odds Ratio \\
\hline \multicolumn{4}{|c|}{ Debt-Related Characteristics } \\
\hline Credit Rejected & 0.88 & $0.06 * * *$ & 2.41 \\
\hline \multicolumn{4}{|l|}{ Not Credit Rejected } \\
\hline Bankruptcy & 0.55 & $0.07 * * *$ & 1.73 \\
\hline \multicolumn{4}{|l|}{ Non- Bankruptcy } \\
\hline Moderate Shopping & -0.13 & 0.07 & 0.87 \\
\hline Intensive Shopping & -0.20 & $0.07 * *$ & 0.81 \\
\hline \multicolumn{4}{|l|}{ No Shopping } \\
\hline \multicolumn{4}{|l|}{ Attitudinal Characteristics } \\
\hline $\begin{array}{l}\text { Conspicuous Spending } \\
\text { No Conspicuous Spending }\end{array}$ & 0.39 & $0.11 * * *$ & 1.48 \\
\hline Overspending & 0.96 & $0.10 * * *$ & 2.63 \\
\hline \multicolumn{4}{|l|}{ Same /Less Spending } \\
\hline \multicolumn{4}{|l|}{ Demographics } \\
\hline 35 to 44 & -0.08 & 0.08 & 0.92 \\
\hline 45 to 64 & 0.06 & 0.08 & 1.06 \\
\hline Older than 65 & -0.52 & $0.16^{* *}$ & 0.59 \\
\hline \multicolumn{4}{|l|}{35 and under } \\
\hline High School/GED & -0.08 & 0.09 & 0.92 \\
\hline College Dropout & 0.21 & $0.10 *$ & 1.23 \\
\hline College & -0.24 & $0.11 *$ & 0.78 \\
\hline \multicolumn{4}{|l|}{ Less than High School/GED } \\
\hline African American & 0.30 & $0.07 * * *$ & 1.35 \\
\hline Hispanic & -0.33 & $0.09 * * *$ & 0.71 \\
\hline Others & 0.19 & 0.15 & 1.21 \\
\hline \multicolumn{4}{|l|}{ White } \\
\hline Married & -0.13 & 0.07 & 0.87 \\
\hline \multicolumn{4}{|l|}{ Not Married } \\
\hline Child/Children & 0.42 & $0.07 * * *$ & 1.53 \\
\hline \multicolumn{4}{|l|}{ No Child } \\
\hline \multicolumn{4}{|l|}{ Financial Characteristics } \\
\hline Salary Earner & -0.04 & 0.07 & 0.95 \\
\hline Self Employed & -0.57 & $0.14 * * *$ & 0.56 \\
\hline \multicolumn{4}{|l|}{ Retired/Not Working } \\
\hline Lower Middle Income & 0.34 & $0.08 * * *$ & 1.40 \\
\hline Upper Middle Income & 0.20 & $0.10 *$ & 1.22 \\
\hline High Income & 0.13 & 0.13 & 1.14 \\
\hline \multicolumn{4}{|l|}{ Low Income } \\
\hline Lower Middle Net Worth & -0.08 & 0.07 & 0.91 \\
\hline Upper Middle Net Worth & -0.85 & $0.13 * * *$ & 0.42 \\
\hline High Net Worth & -3.11 & $0.33 * * *$ & 0.04 \\
\hline \multicolumn{4}{|l|}{ Low Net Worth } \\
\hline Homeowner & -0.47 & $0.08 * * *$ & 0.62 \\
\hline \multicolumn{4}{|l|}{ Non-Homeowner } \\
\hline Intercept & -4.08 & $0.18 * * *$ & \\
\hline
\end{tabular}


school degree/GED. However, once people obtain a college degree, they are less likely to use a payday advance. African Americans tend to use a payday advance, while Hispanics are less likely. Having children has a very strong positive effect on using payday advance loans. Marital status does not have an effect on the probability of borrowing the advanced funds.

Those who are self-employed are less likely to have payday advances than people having different job statuses. Those who are self-employed, with a relatively unstable income, would be less attractive and less reliable clientele for the payday industry. The effect of net worth, expressed as quartile groups, on the probability of borrowing from a payday advance is quite robust. The interpretation of the statistics follows intuition: the lower the net worth, the higher the probability that the respondent will borrow from a payday advance service. However, the level of income is not a clear determinant of the patterns for securing a payday advance. Those who fall in the lower middle income level are more likely to use an advance over those who are in the lowest income level.

\section{CONCLUSIONS AND IMPLICATIONS}

A payday advance has been marketed as short-term credit product to remedy temporary cash-flow problems. The payday advance can be less costly to some borrowers than other options, such as incurring late fees, bouncing a check, or using overdraft protection. Given the easy access to a payday advance and the convenience associated with its loan, such advances have become a large segment of the subprime lending industry.

Despite possible benefits, payday advances have received negative publicity for various reasons. Firstly, a payday advance might finally result in borrowers having to pay exorbitant interest rates. Secondly, the steering of borrowers into high-cost loans has been pronounced in the seemingly risky populations of low-income earners, racial/ethnic minorities, or senior citizens. Thirdly, many payday advance users tend to roll over their loans multiple times (Baddour, 2009) even though the original intent is to cover the immediate shortfall of income. Due to this high rollover rate, borrowers might be trapped and caught in a destructive cycle of debt (Morgan and Pan, 2012). Lastly, the choice to use a payday advance is often determined by borrowers' unrealistic expectations and desperation.

This study aims to shed light on the profile of those who use the risky credit product of a payday advance and the borrowers' demand for using the credit. An understanding of what drives consumers to use this product can inform individual and community-level social work interventions that reduce borrower's financial vulnerability and help them make an educated and right decision that can be of benefit.

The multivariate analyses show that all things being equal, being African Americans, having children, having lower middle income, filing for bankruptcy in the past, being credit constrained, and having a favorable attitude toward a conspicuous spending, and over-spending significantly increase the predicted probability of borrowing from a payday advance business. Those who do intensive shopping for credit and are older than age 65 , have a college degree, and are home owners decrease the probability. The findings show that being economically distressed is a significant and robust component of the probability of using a payday advance. It shows that when credits from mainstream financial institutions are not a readily available option, a consumer might resort to this risky credit product. People with bad credit history might be steered to risky alternative sources of credit. In terms of the demands of payday advance users, about one-third of the payday loan borrowers said it was used for temporary emergency expenses, while $30.1 \%$ of borrowers use the loans for recurring expenses such as basic expenses and other bills/loans. Also, 24.4\% use the loan for convenience. Only $11.6 \%$ of the borrowers withdrew the payday advance because there was no other credit alternative available to them.

\section{Implications for Policy Makers}

As with any type of loan, a payday advance can be 
convenient for some borrowers as a means to obtain money for a short period of time. However, the recent rise in this type of risky credit product, especially its use by financially vulnerable borrowers and those with a tarnished credit score, may have long-term effects impacting their financial health. This study also found that some portions of payday advance users are those who found themselves unable to meet their current living expenses. These borrowers would have no cushion of savings that can be used for unexpected expenses. Repeated use of these types of loans may inhibit the accumulation of wealth for those who already have fewer assets available to consume, invest, and save.

Given the rapid growth in payday advance users, these lending practices and regulations must be subject to stricter scrutiny by policymakers. Especially, in Korea the regulations about total debt to income ratio (DIT), a measure of the credibility of the person and the ability for him/her to repay the loan if it is provided, have recently become ineffective. Thus the regulations against predatory lending and mortgage fraud need to be enforced. Due to historically high levels of personal debt in the country, the Korean government has strengthened guidelines for granting loans (the Korea Times, 2012). Non-banking lenders have also been under a tight watch. Since 2011, 20 of them have been suspended due to bad financial health. However, the strengthened restrictions are backfiring on lowincome earners by forcing them to take on much riskier credit products from payday lenders and other non-banking institutions. The low income earners might be trapped in a vicious cycle where they are forced to go deeper into debt. Therefore, government regulations need to carefully address the risks consumers encounter when refinancing the loans to protect consumers from the predatory lending. For example, capping the number of loans a borrower can receive at one time or requiring loans to be fully amortizing without a balloon payment can be considered. Policy makers should establish guidelines to protect consumers from deceptive lenders by ensuring that lenders that cater to the high risk are held accountable for making loans in accordance with the guidelines. Also, they could give lenders economic incentives when they renegotiate interest rates on loans paid by consumers financially at risk. Community organizations could provide consumers with information on alternative credit resources to meet their needs for cash or low-interest loan to refinance higher interest loan. Borrowers having multiple loans tend to take on risky credit products and end up paying higher interest rates. In order to solve this problem, they need to be provided with opportunities to consolidate loans with a longterm low-interest rate.

\section{Implications for Educators}

As found in this study, one reason people use the risky credit alternative is that they are less likely to seek information associated with borrowing. Many of the payday advance users do not really recognize the actual cost of the loans (Macy, 2010) although Federal Fair Lending Laws in the U.S. requires that borrowers be informed of the actual cost of loans.

Tailored financial education can help consumers develop banking relationships with legitimate and affordable financial institutions and, finally, make reasonable financial decisions. Educated borrowers who understand their rights under lending contracts and know how to exercise those rights would build a solid defense against predatory lenders (Gramlich, 2000). Many varieties of credit options are available and extra options create extra advantages. Each type of credit has different loan terms and fees and it is important to understand them before choosing a loan. Through financial education, borrowers need to be advised to seek information and to consider the overall costs of the loan along with the interest. Borrowers need to decide which option for them is the most preferable and affordable. In addition, borrowers should understand that utilizing risky credit products with short useful lives might hinder their long-term financial goals.

\section{REFERENCES}

Baddour, A. (2009). Short-term cash, long-term debt: The impact of unregulated lending in Texas. Texas Appleseed. 
Bair, S. (2005). Low-cost payday loans: Opportunities and obstacles. Casey Foundation. From http:// www.cfsponline.com/documents/LowCostPaydayLoans.pdf.

Betti, G., Dourmashkin, N., Rossi, M., \& Yin, Y. P. (2007). Consumer over-indebtedness in the EU: Measurement and characteristics. Journal of Economic Studies, 34(2), 136-56.

Bhutta, N., Skiba, P. M., \& Tobacman, J. (2012). How do payday loans affect creditworthiness? Evidence from matched payday applicant-credit record data. From http://assets.wharton.upenn.edu/ tobacman/ papers/Payday \%20Loan\%20Choices\%20and\%20 Consequences\% 2020121010.pdf.

Bhutta, N. (2012). Payday credit access and household financial health: Evidence from consumer credit records. From http://ssrn.com/abstract=1941914 or http://dx.doi.org/10.2139/ssrn.1941914

Bianchi, N. (2012). Profiting from poverty: How payday lenders strip wealth from the working poor for record profits. National People's Action. From http://npa-us.org/files/profiting_from_poverty_npa_ payday_loan_report_jan_2012_0.pdf.

Board of Governors of the Federal Reserve System (2013). Research Resources : Survey of Consumer Finances. From http://www.federalreserve.gov/econresdata/scf/scfindex.htm.

Bucks, B. K., Kennickell, A. B., Mach, T. L., \& Moore, K. B. (2009). Changes in U.S. family finances from 2004 to 2007: Evidence from the Survey of Consumer Finances. Federal Reserve Bulletin, 95, A1-A55.

Caplan, M. E. A. (2011). Gender matters: Economic behavior of payday loan borrowers. Society for Social Work and Research 15th Annual Conference. Tampa, Florida.

Cash Net USA (2012). A little credit: Short-term alternatives to payday loans. From tinyurl.com/DROMCashNet.

Consumer Federation of America. (2012). Comments to the consumer financial protection bureau on payday lending abuses. From http://www.consumerfed.org/news/512.

Crook, J. (1996) Credit constraints and US house- holds. Applied Financial Economics, 6, 477-485.

Crook, J. (2006). Household debt demand and supply: A cross-country comparison", in Bertola, G, Disney, R. and C. Grant, The Economic of Consumer Credit, MIT Press.

Dunn, L. F., \& Mirzaie, I. A. (2012). Determinants of consumer debt stress: Differences by debt type and gender. The Center for Human Resource Research at Ohio State University. Working paper.

Financial News (2013, March 18). 서민들 은행권 $10 \%$ 대 금리 소액대출 '외면'. From http://www.fnnews. $\mathrm{com} /$ view?ra $=$ Sent $0401 \mathrm{~m}$ View\&corp=fnnews\&arcid $=201303190100163250009172 \& \mathrm{cDateYear}=2013 \& \mathrm{cDa}-$ teMonth $=03 \& \mathrm{cDateDay}=18$

Financial Service Centers of America (2009). Fact sheet: Payday advances. From http://www.fisca.org/ Content/NavigationMenu/AboutFISCA/FiSCAFactSheet/FiSCAFactSheetPDA52008.pdf .

Godwin, D. (1998). Household debt quintiles: Explaining changes 1983-1989. Journal of Consumer Affairs, 32(2), 369-393.

Gramlich, E. M. (2000). Remarks at the Federal Reserve Bank of Philadelphia Conference on Predatory Lending, December 6, 2000.

Ibarra, B., \& Rodriguez, E. (2007). Latino credit card use: Debt trap or ticket to prosperity? National Council of Laraza. From http://d1lj5119p3qzy9.cloudfront.net/handle/10207/bitstreams/20249.pdf .

Lawrance, E. C. (1991). Poverty and the rate of time preference: Evidence from panel data. Journal of Political Economy, 99(1), 54-77.

Logan, A., \& Weller, C. E. (2009). Who borrows from payday lenders? Center for American Progress. Center for American Progress. From http://www. americanprogress.org/issues/2009/03/pdf/payday_ lending.pdf

Lusardi, A., \& Mitchell, O. S. (2007). Baby boomer retirement security: The role of planning, financial literacy, and housing wealth. Journal of Monetary Economics, 54, 205-224.

Macy, A. (2010). Cashless at payday: Financial and ethical dilemmas of cash advances. Journal of the International Academy for Case Studies, 16(1), 73-79. 
Morgan, D. P., \& Pan, K. J. (2012). Do payday lenders target minorities? Federal Reserve Bank of New York.

Prager, P. A. (2009). Determinants of the locations of payday lenders, pawnshops and check-cashing outlets. Finance and Economics Discussion Series Divisions of Research \& Statistics and Monetary Aairs. Federal Reserve Board, Washington, D.C.

Seoul News (2012, July 25). 소액 다중채무자 연쇄부도 빨간불. From http://www.seoul.co.kr/news/newsView.php?id=20120625015003\&spage $=1$.

Smale, P. (2005). Payday loans: Federal regulatory initiatives. CRS Report for Congress. Cornell University ILR School.

The PEW Charitable Trusts (2012). Payday lending in America: Who borrows, where they borrow, and why. From http://www.pewstates.org/uploadedFiles/ PCS_Assets/2012/Pew_Payday_Lending_Report.pdf.

The PEW Charitable Trusts (2013). Payday lending in
America. Report 2 : How borrowers choose and repay payday loans. From http://thefinancialbrand.com/wp-content/uploads/2013/03/Pew_Research_ Payday_Lending.pdf.

The Korea Times (2007, September 11). Mortgage a key risk for economy. From http://www.koreatimes.co.kr/www/news/biz/2012/02/123_9997.html.

The Korea Times (2012, July 14). Quality of household debt worsening. From http://www.koreatimes.co.kr/www/news/biz/2012/07/123_114416.html.

Woolsey, B.,\& Schulz, M. (2011). Credit card statistics, industry facts, debt statistics. From http://www. creditcards.com/credit-card-news/credit-card-industry-facts-personal-debt-statistics-1276.php.

Received September 27, 2013

Revised Novmber 7, 2013

Accepted December 3, 2013 